\title{
Techno-economic assessment for energy transition from diesel-based to hybrid energy system-based off-grids in Saudi Arabia
}

\author{
Abdullrahman Abdullah Al-Shamma'a ${ }^{1,3}$ (D) Fahd A. Alturki ${ }^{1} \cdot$ Hassan M. H. Farh ${ }^{1,2}$
}

Received: 18 December 2019 / Accepted: 12 February 2020 / Published online: 27 February 2020

(c) The Author(s) 2020

\begin{abstract}
Hybrid energy power plants are remarkable option for the electrification of isolated areas, which commonly fulfill their energy demand by means of diesel generators. An energy combination comprising also PV or wind systems would lead to a reduction of costs and is, therefore, being gradually esteemed. In this paper, an optimal sizing approach was established based on a long-term energy analysis, to study the techno-economic feasibility of different hybrid systems proposed to electrify an isolated area located in the north of Saudi Arabia under different fuel cost scenarios. For each fuel cost scenario, the hybrid system has been designed and optimized to get a maximum renewable penetration ratio at a low cost of energy. An optimization model based on genetic algorithm is developed to determine the optimum hybrid systems. Three different systems are studied, with different diesel price, to relatively analyze the different hybrid systems and the result reveals that $\mathrm{PV} /$ battery/diesel with zero LPSP is the most cost-effective system for the proposed remote area. Sensitivity analysis reveals that that the hybrid systems is the most economically choice even if the solar radiation decreases to half. It also found that irrespective of the wind speed, PV/battery/diesel system is the optimal choice if the wind speed is less than about $6.75 \mathrm{~m} / \mathrm{s}$. At solar radiation and wind speed less than $1500 \mathrm{~W} / \mathrm{m}^{2}, 5.6 \mathrm{~m} / \mathrm{s}$, respectively, diesel only system is cost effective. According to the present results, there is a good economic prospective to shift the diesel plants to hybrid systems, with cost reduction opportunities of around $41 \%$ of the cost of energy.
\end{abstract}

Keywords Hybrid energy system · Loss of power supply probability $\cdot$ Annualized system cost $\cdot$ Renewable energy fraction $\cdot$ Genetic algorithm $\cdot$ Cost of energy $\cdot$ Diesel price

\section{Introduction}

In Saudi Arabia, electric grid is broadly spread for continuous and high power quality supply. However, there are many remote areas, which are not connected to the public utility grid. Generally, diesel generators units are one of the

Abdullrahman Abdullah Al-Shamma'a

ashammaa@ksu.edu.sa

Fahd A. Alturki

falturki@ksu.edu.sa

Hassan M. H. Farh

hfarh@ksu.edu.sa

1 Electrical Engineering Department, College of Engineering, King Saud University, Riyadh 11421, Saudi Arabia

2 Malaysia-Japan International Institute of Technology, Universiti Teknologi Malaysia, Kula Lumpur, Malaysia

3 Department of Mechatronics Engineering, College of Engineering, Taiz University, Taiz, Yemen suitable options to supply energy to those areas due to their compact design, high specific power and low initial cost. Since fossil fuel price has been increasing in the last decade, the generation and maintenance cost have been also increased. Also, the operation and maintenance cost of diesel generators is highly affected by load demand profiles, where the maximum efficiency is accomplishes only when the diesel generator operate near its rated capacity. Furthermore, burning fossil fuel emits severe gases such as $\mathrm{CO}_{2}$ which is the main cause of greenhouse effect [1]. Hence, there is a need to diminish the dependency on fossil fuel to generate electricity. In recent times, the renewable systems such as PV and wind turbine are being extensively used to lessen fuel consumption for electricity generation. From a practical prospective neither a PV system only nor a wind system only can deliver an uninterrupted supply due to periodical deviations of these systems [2].

Depending on the availability of renewable resources and load profile, sometime two resources or more mixed 
together to form hybrid energy system (HES) [3]. This kind of HES mitigates single system variations and decreases the storage elements which in turn decrease overall system costs [4]. However, the optimal sizing of hybrid systems is more complicated compared with single energy sources due to the nonlinear behavior of the system resources and high number of factors that have to be deliberated for the optimal sizing [5]. Moreover, the mutual dependent between the optimal sizing and the energy management strategy of the HES, makes the optimal sizing of such systems complicated. Therefore, optimal sizing approach is crucial step to exploit the renewable energy systems efficiently and economically [6]. The optimum sizing approach uses the cost of energy (COE) as cost function to be minimized. It necessitates the evaluation of the long-term performance of the HES to achieve the best compromise between power system reliability and investment cost [7].

Numerous researches have been conducted in the field of optimization of HES, such as iterative, graphical, linear programming, probabilistic, metaheuristics methods and others. The main goal of each method is to find the optimum values of the system parameters for a given configuration. Thus, Yang et al. [8] introduced an optimum sizing model based on iterative optimization method called HSWSO to optimize HES that consists of PV/wind/battery. This model is comprised of three main models: components model such as PV array, wind turbine and battery bank; the reliability model based on loss of power supply probability (LPSP) technique; and the economic model based on COE. The system with the lowest LCE is considered as the cost-effective optimum configuration. Diaf et al. [9] utilized iterative optimization technique to conduct techno-economic optimization of HES that consists of PV/wind turbine with/without uninterruptible power supply (UPS) to supply an assumed load to be installed at three selected locations in Corsica Island in France. The main objective of these studies is to optimize the dimensions of HES components which guarantee the lowest LCE, while the second objective is to compare the performance of $\mathrm{PV} /$ wind turbine/UPS and PV/wind turbine/without UPS. According to the author's results, the type of the system configuration have an effect on the LCE and on the battery state of charge (SOC) profile, mainly at low windy sites. Similarly, Kaabeche et al. [10] introduced an optimization model based on iterative optimization technique of $\mathrm{PV} /$ wind hybrid system which is planned to supply residential household located in Algeria. The optimization process is conducted based on LPSP and the relativity excess power generated for power system reliability, while the economical part is done based levelised COE, total annualized cost and break-even distance. The optimized decision parameters are the number of PV arrays, number of wind turbine at different autonomy day of the battery capacity. Ferrari et al. [11] utilized GA to optimally size hybrid PV/wind turbine/diesel energy system proposed to supply remote mountain chalet in Italian Alps. The GA optimized the proposed configuration by minimizing LPSP and annualized cost of system using three different load profiles. The impact of component characteristics on the optimal HES is also investigated. A techno-economic valuation of a hybrid PV/ battery/diesel system for an isolated Malaysian community is introduced by Ismail et al. [12]. The PV/battery/diesel HES was found to be the most visible choice. The two other options examined exhibit higher values for COE. In [13], the optimal HES is not accomplished only via choosing the configuration with the lowest COE but also by selecting an appropriate renewable energy fraction that supply the load with zero LPSP. Additionally, nine hybrid systems were explored and weighed against their economical, technical and environmental performance. For each scenario, the HES were optimized to achieve a maximum output power at a low COE.

In this research, two hybrid system with battery banks as energy storage system to supply a typical load demand in an isolated area in Saudi Arabia is investigated under different diesel price. An optimization model based on genetic algorithm is used to determine the optimum HES. Four parameters were included in the proposed technique; PV array power, wind turbine rated power, number of battery banks, and diesel generator rated power. To use this model, an hourly data bank of the solar radiation, wind speed and load demand for the desired site must be available. The technical specifications and costs of the system equipment are also needed. The proposed model shows all the possible configurations (renewable energy sources capacity, number of battery banks, diesel generator rated power, operational hours, fuel consumption, renewable energy fraction, etc.) that fulfills the load demand requirements. The proposed technique has been applied to assess the technical and economic conditions of transitioning isolated area in Saudi Arabia to HES based systems. While PV system is often considered as too expensive and not competitive enough with conventional systems, this research demonstrates that the COE could decrease by $45 \%$ when using HES.

\section{Case study}

The purpose of this paper is to explore the techno-economic feasibility of two stand-alone HES in remote area in Saudi Arabia. Isolated villages near Arar in Saudi Arabia which are not linked to the public grid were selected. These villages having reasonable solar radiation and wind speed and having information on the public living necessities. In these settlements, the load requirements are satisfied using diesel power stations $[14,15]$. These stations are operated either by Saudi Electricity Company (SEC) or by private contractors. 


\section{Hybrid energy systems configurations}

The proposed HES that were applied to supply the load requirements of the villages under study compose of the following techniques:

- Photovoltaic, battery banks and diesel generator (PV/battery/DG).

- Wind turbine, battery banks and diesel generator (WT/ battery/DG).

These systems were then investigated, assessed and compared against their performance through this study. The assessment of the diesel price effects on optimal renewable energy fraction is crucial to this study. Figures 1, 2 show the PV-diesel-battery and WT-diesel-battery hybrid energy systems.

During the system operational different cases were distinguished, as shown in Fig. 3:

- If load demand $\left(E_{L}(t)\right)$ is less than the power produced from renewable resources $\left(P_{W T}(t)\right.$ or $\left.P_{\mathrm{PV}}(t)\right)$, then excess power will be used to charge the battery via converter and charge controller. If battery banks capacity $\left(C_{\text {Batt }}\right)$ reaches it maximum level $\left(\mathrm{SOC}_{\max }\right)$, then excess power will be dissipated.

- If the power produced from renewable resources is higher than load demand $\left(E_{L}(t)\right)$, the shortage will be delivered by battery if state of charge of battery banks $(\operatorname{SOC}(\mathrm{t}))$ is higher than minimum value $\left(\mathrm{SOC}_{\mathrm{min}}\right)$.

- If the total energy generated from renewable energy resources is less than the load demand and $\mathrm{SOC}(\mathrm{t})$ of battery banks is equal to $\mathrm{SOC}_{\text {min }}$, diesel generator (DG) will be run to supply the load as follows:

- If the shortage is less than the minimum working point of the DG $\left(P_{\mathrm{DG} \text { in }}\right)$, then DG will be run at $P_{\mathrm{DG} \text { min }}$ and excess will be dissipated.

- While if the shortage is higher than $P_{\mathrm{DGmin}}$ and less than DG rated power $\left(P_{\mathrm{DGrated}}\right)$, the shortage will be delivered by DG. Else, if the shortage is higher than $P_{\text {DGrated }}$, DG will be run at the rated power and the lacking energy will delivered by battery banks if stored level is enough.

- The LPSP can be calculated using [6]

LPSP $=\frac{\sum_{t=0}^{T} \text { Power Failure Time (PFT) }}{T}$.

- The PFT is defined as the time that the load is not fulfilled when the generated power is inadequate and SOC of battery banks is equal to $\mathrm{SOC}_{\mathrm{min}}$.

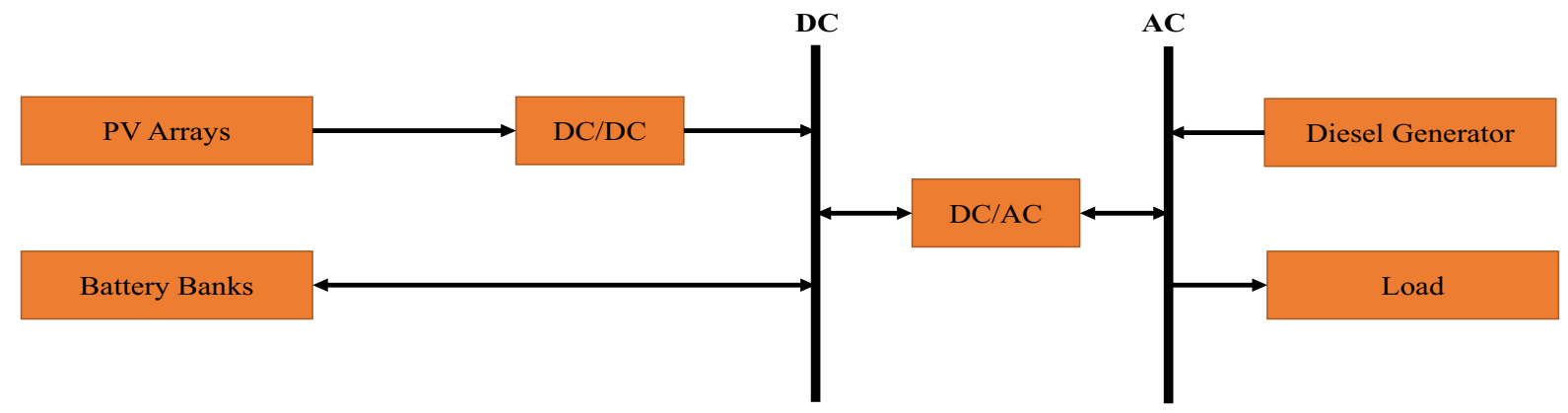

Fig. 1 Structure of the PV-diesel-battery HES



Fig. 2 Structure of the wind-diesel-battery HES 


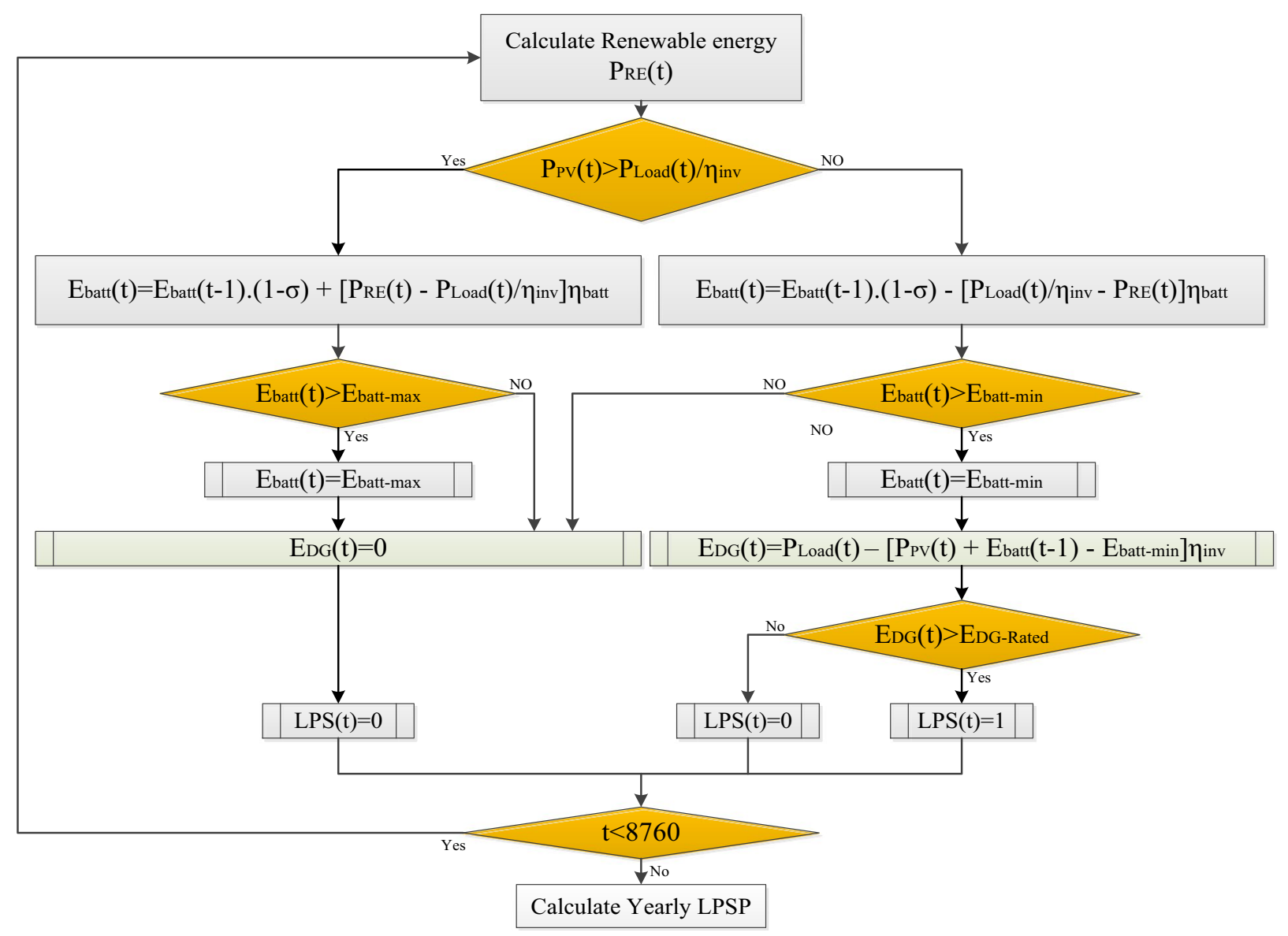

Fig. 3 Flowchart of LPSP calculation

\section{Hybrid energy system modeling}

\section{Photovoltaic system}

The mathematical model for calculation the output power of PV system is consisted of two parts: solar radiation conversion model and photovoltaic module power model.

\section{Solar radiation conversion module}

The PV module can be positioned at any tilted angle and at any orientation. Since most stations only record solar irradiance on a horizontal plane, an estimation of the global solar irradiance incident on tilted PV system is necessary.

In general, the global solar irradiance on any tilted plan $G_{G \text {,tilted }}$ can be calculated using

$G_{G, \text { tilted }}=G_{\text {dir,tilted }}+G_{\text {diff,tilted }}+G_{\text {ref,tilted }}$,

where $G_{\text {dir,tilted }}, G_{\text {diff,tilted }}$ and $G_{\text {ref,tilted }}$ are the hourly direct, diffuse and reflected radiation on tilted plan. The tilted diffused solar radiation can be calculated using the model proposed by Daif [11].

\section{Photovoltaic model}

The PV output power can be approximated using the solar irradiance incident on tilted $\mathrm{PV}$, the ambient temperature and the manufacturer information for the PV module [16]:

$P_{\mathrm{PV}}=P_{R} f_{\mathrm{PV}}\left(\frac{\overline{G_{T}}}{\overline{G_{T, \mathrm{STC}}}}\right)\left[1+\alpha_{P}\left(T_{c}-T_{c, \mathrm{STC}}\right)\right]$,

where $P_{R}$ is the PV module nominal power; $\overline{G_{T, \text { STC }}}$ and $T_{c, \mathrm{STC}}$ are the incident irradiance and PV temperature under standard test conditions (STC), respectively; $\overline{G_{T}}$ and $T_{c}$ are the incident irradiance and the temperature of the tilted PV array, respectively; $\alpha_{P}$ and $f_{\mathrm{PV}}$ are the temperature coefficient of power and the PV derating factor, respectively. The temperature of the PV module can be calculated using [16] 
$T_{c}=\frac{T_{a}+\left(\mathrm{NOCT}-T_{a, \mathrm{NOCT}}\right)\left(\frac{\overline{G_{T}}}{G_{T, \mathrm{NOCT}}}\right)\left[1-\frac{\eta_{m p}}{0.9}\right]}{1+\left(\mathrm{NOCT}-T_{a, \mathrm{NOCT}}\right)\left(\frac{G_{T}}{G_{T, \mathrm{NOCT}}}\right)\left(\frac{\alpha_{P} \eta_{m p, S T C}}{0.9}\right)}$,

where $T_{a}$ the PV module ambient temperature; NOCT is the nominal operating cell temperature; $T_{a, \mathrm{NOCT}}$ is the PV module ambient temperature at the NOCT conditions; $G_{T, \mathrm{NOCT}}$ is the solar irradiance under NOCT conditions; $\eta_{\mathrm{mp}, \mathrm{STC}}$ is the maximum power point efficiency under STC; $\eta_{\mathrm{mp}}$ is the maximum power point efficiency.

The $\eta_{\mathrm{mp}}$ is given according to the following equation [16]:

$\eta_{\mathrm{mp}}=\eta_{\mathrm{mp}, \mathrm{STC}}\left(1-\alpha_{P} T_{c, \mathrm{STC}}\right)$.

Consequently, when the solar irradiance on the tilted photovoltaic module and the ambient temperature are identified, the hourly output power of the photovoltaic system can be calculated using Eq. 3 .

\section{Wind system}

The output power of wind turbine depends on three main parameters; the wind turbine rated power $\left(P_{r}\right)$, cut-in speed $\left(V_{c}\right)$, rated speed $\left(V_{r}\right)$, and cutoff speed $\left(V_{f}\right)[17$, 18]. Figure 4 shows typical wind turbine characteristics based on a quadratic model. The wind turbine output power $P_{W T}(V)$ can be calculated using [17]

$P_{\mathrm{WT}}(V)=P_{r} \times\left\{\begin{array}{cc}0 & V\left\langle V_{c} \text { or } V\right\rangle V_{f} \\ \frac{V^{2}-V_{c}^{2}}{V_{r}^{2}-V_{c}^{2}} & V_{c} \leq V \leq V_{f} \\ 1 & V_{r} \leq V \leq V_{f}\end{array}\right.$

Since the wind speed are commonly recorded at standard altitude $(10 \mathrm{~m}$ or $20 \mathrm{~m})$; thus, it is necessary to do some approximation from measured wind speeds.

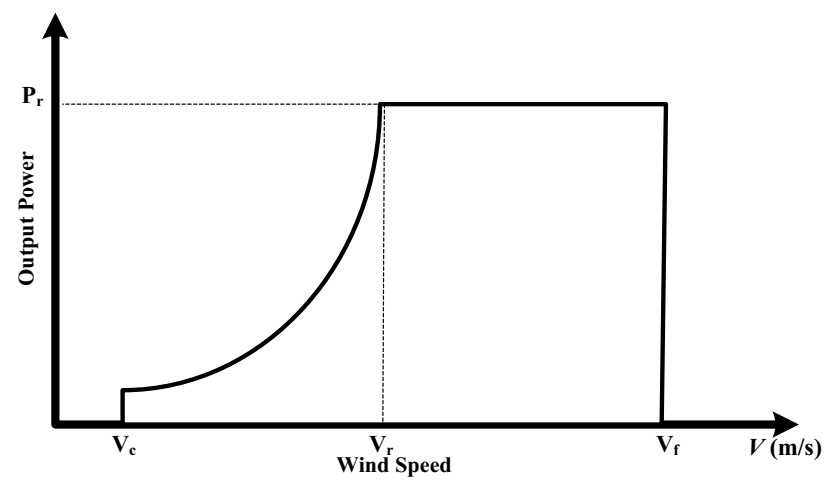

Fig. 4 Wind turbine output power characteristics
The wind profile power law is one of the most common approaches and can be defined by

$V_{\text {hub }}=V_{\text {data }}\left(\frac{Z_{\text {hub }}}{Z_{\text {data }}}\right)^{\alpha}$,

where $V_{\text {hub }}$ is the wind speed at the hub height $Z_{\text {hub }}$, and $V_{\text {data }}$ is the measured wind speed at the measured height $Z_{\text {data }}$ and $\alpha$ is power low exponent. In this paper, the wind speed is recorded at $30 \mathrm{~m}$ AGL by KACST and it is extrapolated to $60 \mathrm{~m}$ AGL using $\alpha=1 / 7$.

\section{Diesel generator model}

Diesel generator (DG) is necessary to meet the load requirements once the total power produced from renewable resources and storage system is not sufficient to supply the load requirements. The fuel consumption and the annual fuel cost can be calculated by the following equation [19]:

$C_{D G}=C_{F} \sum_{t=1}^{8760} F(t)$

where $F(t)$ is the DG fuel consumption per hour and it can be found using

$F(t)=A \times P_{\mathrm{DG}}(t)+B \times P_{R}$,

where $P_{R}$ and $P_{D G}(t)$ are the rated power and generated power of the DG, respectively, $C_{F}$ is the diesel price per liter and $\mathrm{A}$ and $\mathrm{B}$ are the fuel curve constant [19].

It can be seen from the above equation that the fuel consumption of the DG depends on the rated power and generated power. Consequently, DG should not work below its minimum setting. Usually, the manufacturers give a recommendation about the generator minimum setting; therefore, the operation of DG has to be in the range between the rated power and minimum value [20] and mathematically it can be expressed as follows:

$P_{\mathrm{DG}, \min } \leq P_{\mathrm{DG}}(t) \leq P_{D G, \max }$.

\section{Battery bank model}

Storage system is crucial part in any renewable energy system. since renewable resources output power are not regularly available due to the meteorological environments. Therefore, storage system is used to supply the deficient energy. The state of charge (SOC) of battery bank depends on the total power generated from renewable resources and can be calculated using [21]:

- Charging mode 


$$
\begin{aligned}
& \operatorname{SOC}(t)=\operatorname{SOC}(t-1)(1-\sigma) \\
& \quad+\left(E_{\mathrm{GA}}(t)-\frac{E_{L}(t)}{\eta_{\mathrm{inv}}}\right) \eta_{\text {battery }}: E_{\mathrm{GA}}>\frac{E_{L}(t)}{\eta_{\mathrm{inv}}} .
\end{aligned}
$$

- Discharging mode

$$
\begin{aligned}
& \operatorname{SOC}(t)=\operatorname{SOC}(t-1)(1-\sigma) \\
& \quad+\left(E_{\mathrm{GA}}(t)-\frac{E_{L}(t)}{\eta_{\mathrm{inv}}}\right) \eta_{\text {battery }}: E_{\mathrm{GA}}<\frac{E_{L}(t)}{\eta_{\mathrm{inv}}},
\end{aligned}
$$

Where $E_{\mathrm{GA}}(t), E_{L}(t), \eta_{\text {inv }}, \sigma$ and $\eta_{\text {battery }}$ and are the total generated power, total load demand, inverter efficiency, selfdischarging factor and charge efficiency of battery bank, respectively. The value of $\mathrm{SOC}(t)$ could not be less than a minimum permissible energy point which must be remain in battery bank $\left(\mathrm{SOC}_{\min }\right)$. In addition, while charging operation, the value of $\mathrm{SOC}(t)$ could not be higher than a maximum permissible energy point $\left(\mathrm{SOC}_{\max }\right)$. Mathematically it can be expressed as follows [22]:

$\mathrm{SOC}_{\min } \leq \mathrm{SOC}(t) \leq \mathrm{SOC}_{\max }$

The maximum state of charge, $\mathrm{SOC}_{\max }$ equal the nominal capacity of battery bank, $C_{\mathrm{Batt}}$ and the minimum state of charge, $\mathrm{SOC}_{\mathrm{min}}$, is depends on the battery bank depth of discharge, DOD: $\mathrm{SOC}_{\min }=(1-\mathrm{DOD}) C_{\mathrm{Batt}}$.

\section{Renewable energy fraction model}

The renewable energy fraction (REF) is the amount of energy produced form renewable resources that goes to supply the load and it can be expressed using [16]

$\mathrm{REF}=\left(1-\frac{E_{L, \mathrm{DG}}}{E_{L, \text { served }}}\right) \times 100$,

where $E_{L, \mathrm{DG}}$ is the amount of load demand supplied by the DG. Pure renewable system equivalent to REF of $100 \%$, whereas pure DG equivalent to REF of $0 \%$ and the remaining values between these boundaries correspond to HES.

\section{Economic model}

The COE concept is used as a benchmark of the hybrid system cost investigation in this paper. The COE is defining as the average cost per $\mathrm{kWh}$ of useful energy generated by the HES and can be expressed as [16]

$\mathrm{COE}=\frac{\text { Annualized system } \operatorname{cost}(\mathrm{ASC})}{\text { Load served }\left(E_{L, \text { served }}\right)}$.
The ASC is calculated by adding the annualized capital $\operatorname{cost} C_{\text {acap }}$, annualized replacement $\operatorname{cost} C_{\text {arep }}$ and annualized maintenance $\operatorname{cost} C_{\text {amain }}$ :

$\mathrm{ASC}=C_{\mathrm{acap}}+C_{\mathrm{arep}}+C_{\mathrm{amain}}$.

The annualized capital cost is expressed using the following equation:

$C_{\text {acap }}=C_{\text {cap }} \operatorname{CRF}\left(i, Y_{\text {proj }}\right)$,

where CRF is the capital recovery factor, $C_{\text {cap }}$ is the total capital cost; $Y_{\text {proj }}$ is project lifetime.

The $C_{\text {cap }}$ can be expressed using

$C_{\text {cap }}=C_{\text {renwable }}+C_{\text {Batt }}+C_{\mathrm{DG}}$,

where $C_{\text {renewable }}, C_{\mathrm{Batt}}$ and $C_{\mathrm{DG}}$ are the capital cost of the renewable component, battery bank and DG.

The capital recovery factor is expressed using

$\operatorname{CRF}\left(i, Y_{\text {proj }}\right)=\frac{i(1+i)^{Y_{\text {proj }}}}{(1+i)^{Y_{\text {proj }}}-1}$.

The annualized replacement cost can be calculated using

$C_{\text {arep }}=C_{\text {rep }} S S F\left(i, Y_{\text {rep }}\right)$,

where $C_{\text {rep }}$ is the capital replacement cost, SSF is the sink fund factor, $Y_{\text {rep }}$ is the lifetime of the component.

The sinking fund factor is calculated using

$\operatorname{SSF}\left(i, Y_{\text {proj }}\right)=\frac{i}{(1+i)^{Y_{\text {rep }}}-1}$.

Technical information of each component is essential to correctly investigate the performance of each of the nominated HES. Additionally, the cost of each components of the chosen HES was also necessary to evaluate the economic performance and, consequently, the COE of each HES. The technical information of the battery bank, photovoltaic module, and the wind turbine speed characteristics are listed in Tables 1, 2 and 3, respectively. The cost information of the system components is listed in Table 4. The hourly data of load demand, wind speed and solar irradiation during 1 year is plotted in Figs. 5 and 6.

Table 1 Battery specifications

\begin{tabular}{llllll}
\hline Model & $\begin{array}{l}\text { Nominal } \\
\text { capacity } \\
\text { (Ah) }\end{array}$ & $\begin{array}{l}\text { Voltage } \\
(\mathrm{V})\end{array}$ & $\mathbf{\eta}_{\mathbf{B}}(\%)$ & DOD (\%) & $\begin{array}{l}\text { Life time } \\
\text { (year) }\end{array}$ \\
\hline $\begin{array}{c}\text { Surrette- } \\
\text { 6CS25P }\end{array}$ & 1156 & 6 & 80 & 60 & 12 \\
\hline
\end{tabular}


Table 2 Photovoltaic module specifications

\begin{tabular}{llllllll}
\hline Model & $\begin{array}{l}\text { Maximum power } \\
\left(P_{\mathrm{mp}}, \mathrm{W}\right)\end{array}$ & $\begin{array}{l}\text { Nominal voltage } \\
\left(V_{\mathrm{nom}}, V\right)\end{array}$ & $\begin{array}{l}\text { Module efficiency } \\
\left(\eta_{\mathrm{mp}}, \%\right)\end{array}$ & $\begin{array}{l}\text { Temperature } \\
\text { coefficient of } P_{\mathrm{mp}} \\
(\% / 0 \mathrm{C})\end{array}$ & $\begin{array}{l}\text { Temperature } \\
\text { coefficient of Isc } \\
(\% / 0 \mathrm{C})\end{array}$ & $\begin{array}{l}\text { Temperature } \\
\text { coefficient of } V_{\mathrm{oc}} \\
(\% / 0 \mathrm{C})\end{array}$ & $\begin{array}{l}\text { NOCT }(0 \mathrm{C}) \\
\text { BP3135 }\end{array} 135$ \\
\hline
\end{tabular}

Table 3 Wind turbine speed characteristics

\begin{tabular}{lllll}
\hline $\begin{array}{l}\text { Rated power } \\
(\mathrm{kW})\end{array}$ & \multicolumn{2}{l}{ Speed characteristics $(\mathrm{m} / \mathrm{s})$} & \\
\cline { 2 - 4 } & $\begin{array}{l}\text { Cut-In speed } \\
(\mathrm{m} / \mathrm{s})\end{array}$ & $\begin{array}{l}\text { Rated speed } \\
(\mathrm{m} / \mathrm{s})\end{array}$ & $\begin{array}{l}\text { Cutoff speed } \\
(\mathrm{m} / \mathrm{s})\end{array}$ & $\begin{array}{l}\text { Hub height } \\
(\mathrm{m})\end{array}$ \\
\hline- & 3 & 12 & 25 & 60 \\
\hline
\end{tabular}

\section{Computer model}

The final step of this study is to develop an optimization model based on the aforementioned collected data to find the optimum PV array capacity/WT rated power and number of battery banks. The desired REF and LPSP values must also specified. The maximum rated power of DG is nominated to meet the peak load demand. The flow chart of the proposed model is presented in Fig. 7. The battery bank is permitted to discharge up to its minimum state of charge $\left(\mathrm{SOC}_{\min }\right)$. PV arrays power, WT rated power, diesel generator rated power and the number of battery banks randomly chosen becomes the chromosomes of GA. The proposed model validates if the chosen chromosomes fulfilled the technical constraints (LPSP and REF). If the chosen chromosome has a lower COE than the previous $\mathrm{COE}$ achieved from the previous generation, this chromosome is chosen to be the optimal solution in the current generation. The optimal chromosome will be altered by enhanced solutions created in following genetic algorithm generations. Therefore, as to generate the next population, once the selection process is accomplished, the optimal chromosome will then be susceptible to the crossover and mutation operations. This steps is repeated until the termination condition has been achieved and each new generation subjects to the desired LPSP and REF:

LPSP $\leq$ LPSP $_{\text {set }}$ and REF $\leq \mathrm{REF}_{\text {set }}$.
Table 4 Capital cost and lifetime of the system components [23-25]

\begin{tabular}{llllr}
\hline Component & Initial cost & Replacement cost & O and M & Life time \\
\hline PV module & $1000[\$ / \mathrm{kW}]$ & Null & $15[\$ / \mathrm{kW}]$ & 20 \\
Wind turbine & $1300[\$ / \mathrm{kW}]$ & Null & $30.33[\$ / \mathrm{kW}]$ & 20 \\
Battery bank & $200[\$ / \mathrm{kWh}]$ & $200[\$ / \mathrm{kWh}]$ & $5[\$ / \mathrm{kWh}]$ & 5 \\
Inverter & $133[\$ / \mathrm{kW}]$ & $100[\$ / \mathrm{kW}]$ & $10[\$ / \mathrm{kW}]$ & 10 \\
Diesel Generator & $300[\$ / \mathrm{kW}]$ & $300[\$ / \mathrm{kW}]$ & $0.012[\$ / \mathrm{kWh}]$ & 10 \\
\hline
\end{tabular}

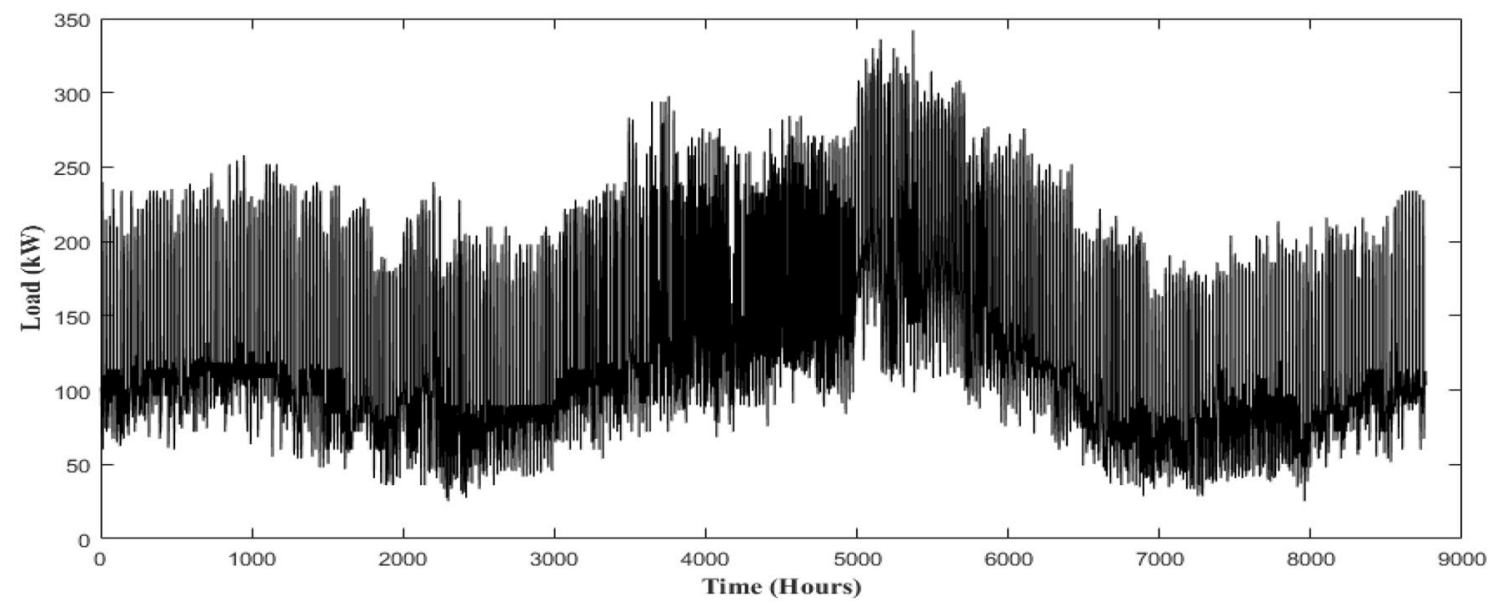

Fig. 5 Load demand for the village under study 

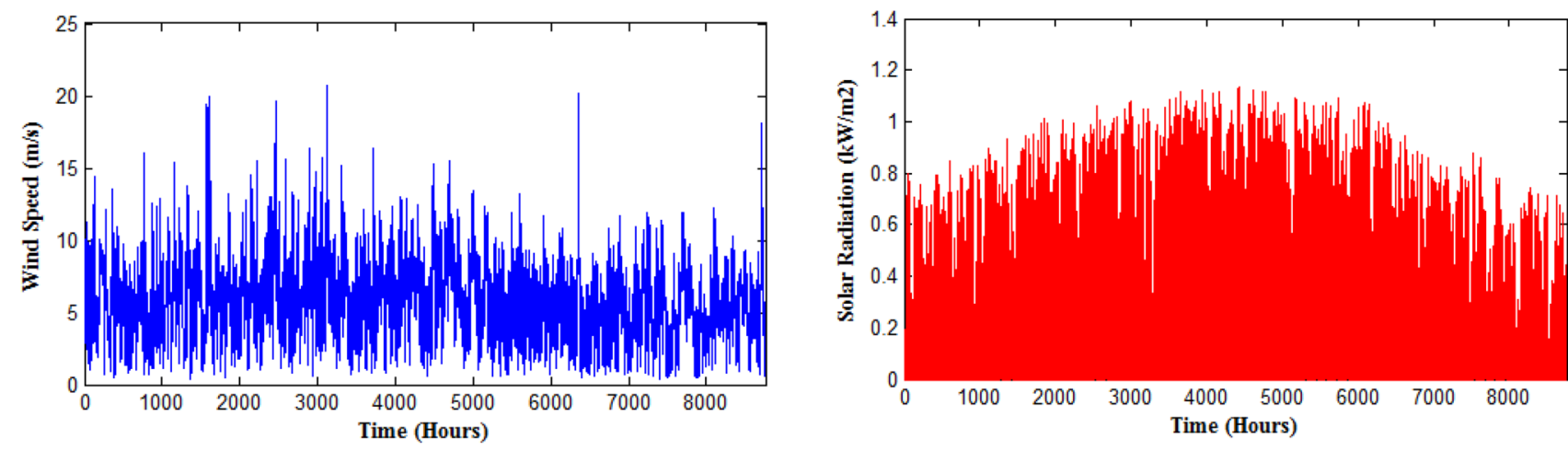

Fig. 6 Hourly data of wind speed and solar irradiance

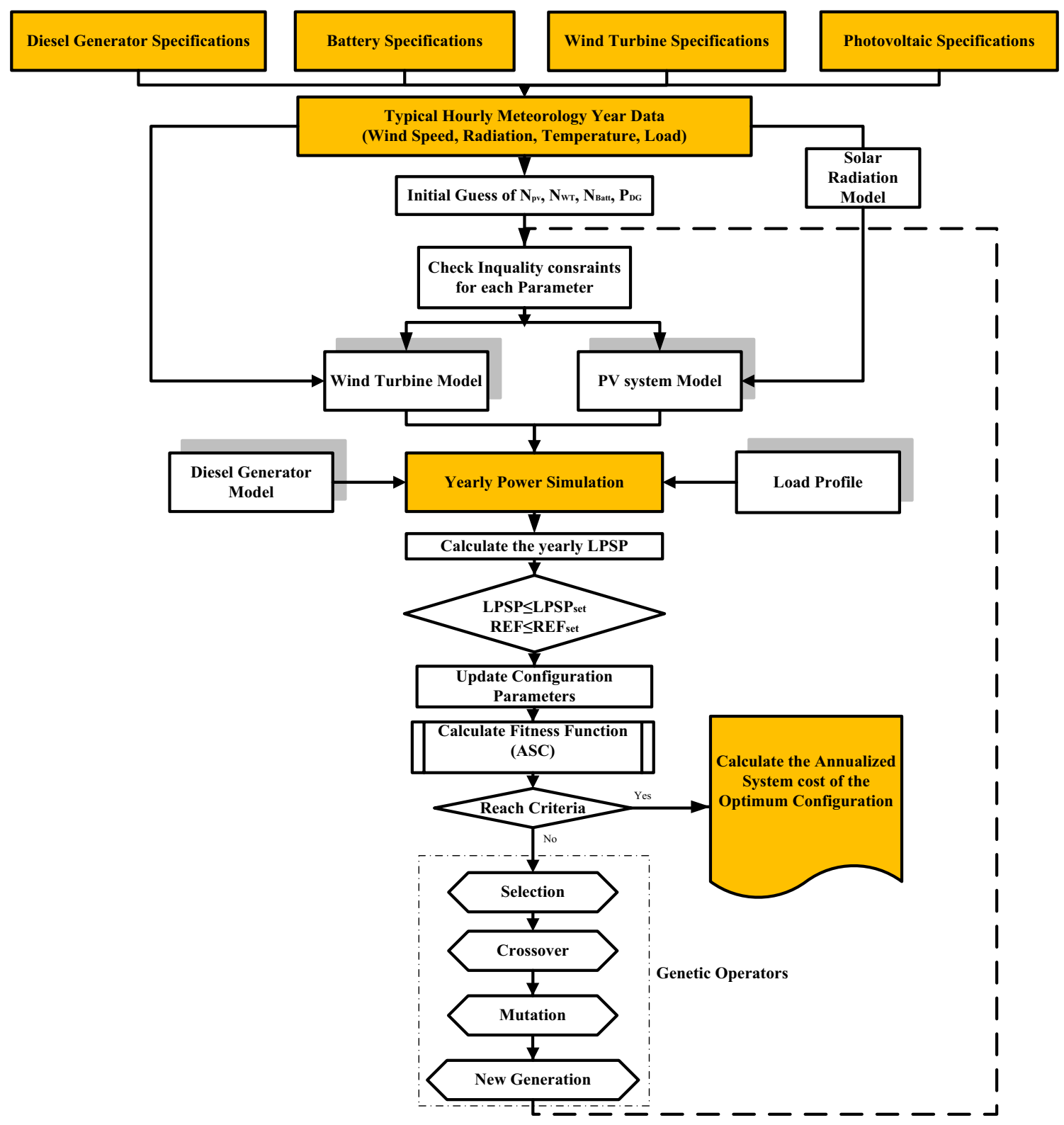

Fig. 7 Proposed optimization model 


\section{Results and discussion}

GA code-based Matlab program has been created to discover the optimum design of the two HES under study. The GA parameters comprise of 100 populations, and 300 maximum generations. The crossover and mutation rates are taken to be 0.7 and 0.25 , respectively. Each chromosome contains three genes represents PV capacity/WT rated power, diesel generator rated power and number of battery banks. This study explores a proper combination of wind turbine, PV array, diesel generator and the battery banks to match the load requirements as shown in Table 5 .

To perform the simulation, different cases are considered as follows:

- Optimal HES consists of PV array, battery and DG (PV/diesel/battery).

- Optimal HES consists of wind turbine, battery and DG (wind/diesel/battery).

- Optimal HES consists of PV array and DG (PV/diesel).

- Diesel generator system (diesel only).

In each case study, the optimal sizing is performed and compared on the basis of key indicators, i.e., LPSP, COE and REF, to achieve an economical and optimal autonomous HES. It can be seen that PV/diesel/battery system has lowest COE (0.063135\$/kWh) value as compared to the other optimal systems under subsidized diesel price $(0.13 \$ / \mathrm{L})$. The PV/diesel/battery system has comparatively lowest COE due to the elimination of the storage bank, while as wind/diesel/battery system has the highest $\mathrm{COE}$ as well as replacement cost due to the larger storage bank size. The fuel saving using HES systems based on $0.13 \$ /$ Liter as compared to the diesel only system is approximately $60 \%$, whereas, the percentage decrease in carbon emissions of the optimum HES is about $43 \%$ as compared to the diesel only system.

Figures 8 and 9 manifest the variation of the REF and the COE of wind/battery/diesel and PV/battery/diesel hybrid systems for zero LPSP as a function of the diesel price. It can be observed that the optimum REF increases as the diesel price increases, for a given wind speed and solar radiation. As shown in this figure, with increasing the diesel price, the role of the DG in energy generation becomes less and decreases by $20-55 \%$.

To determine the effect of increasing diesel prices on the COE of the best system configurations, the minimum COE curves of the system configurations meeting the LPSPs of $0 \%$ are shown in Fig. 8. With the elimination of diesel price subsidies (assuming a diesel price $0.1-0.5$ $\$ / \mathrm{L}$ ) the PV/battery/diesel system with DG rated power between 300 and $200 \mathrm{~kW}$, PV array power between 280

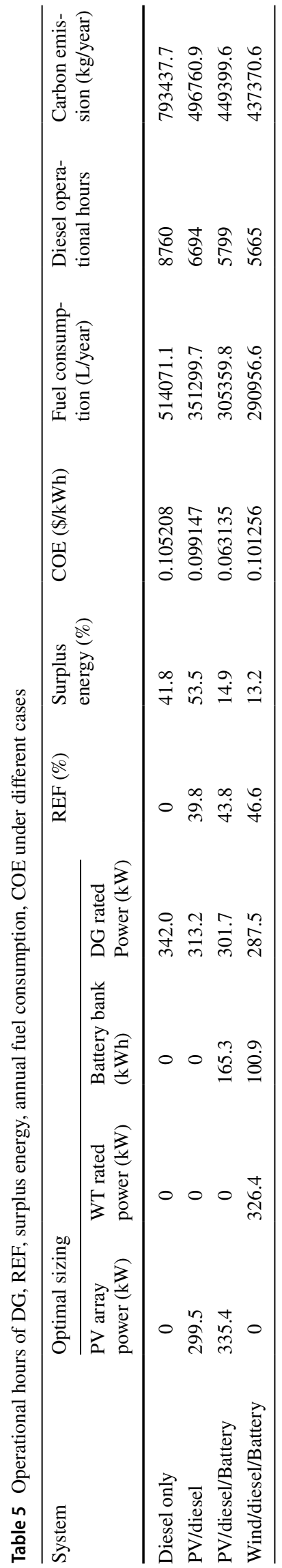




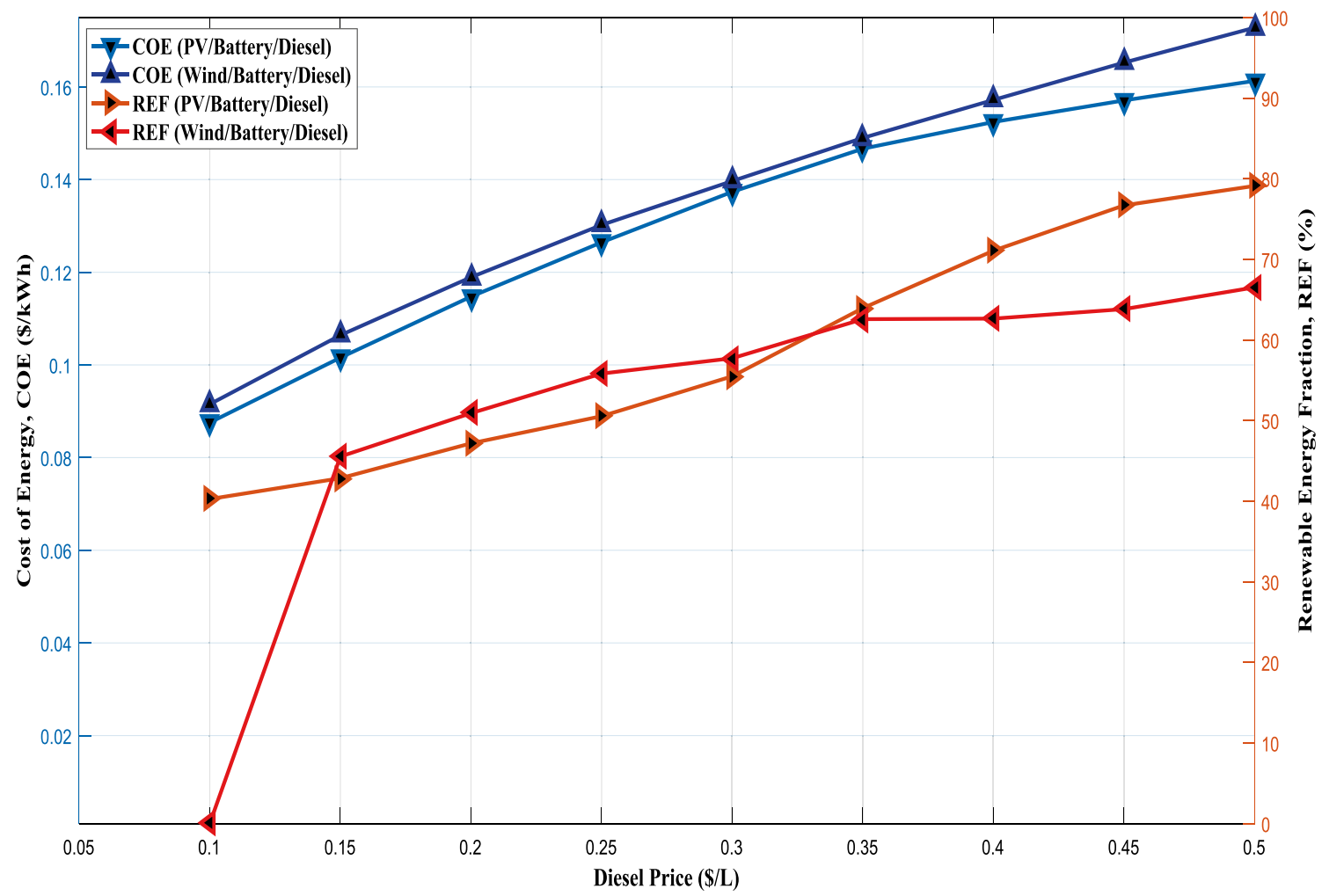

Fig. 8 Impact of diesel price on renewable penetration ratio and COE
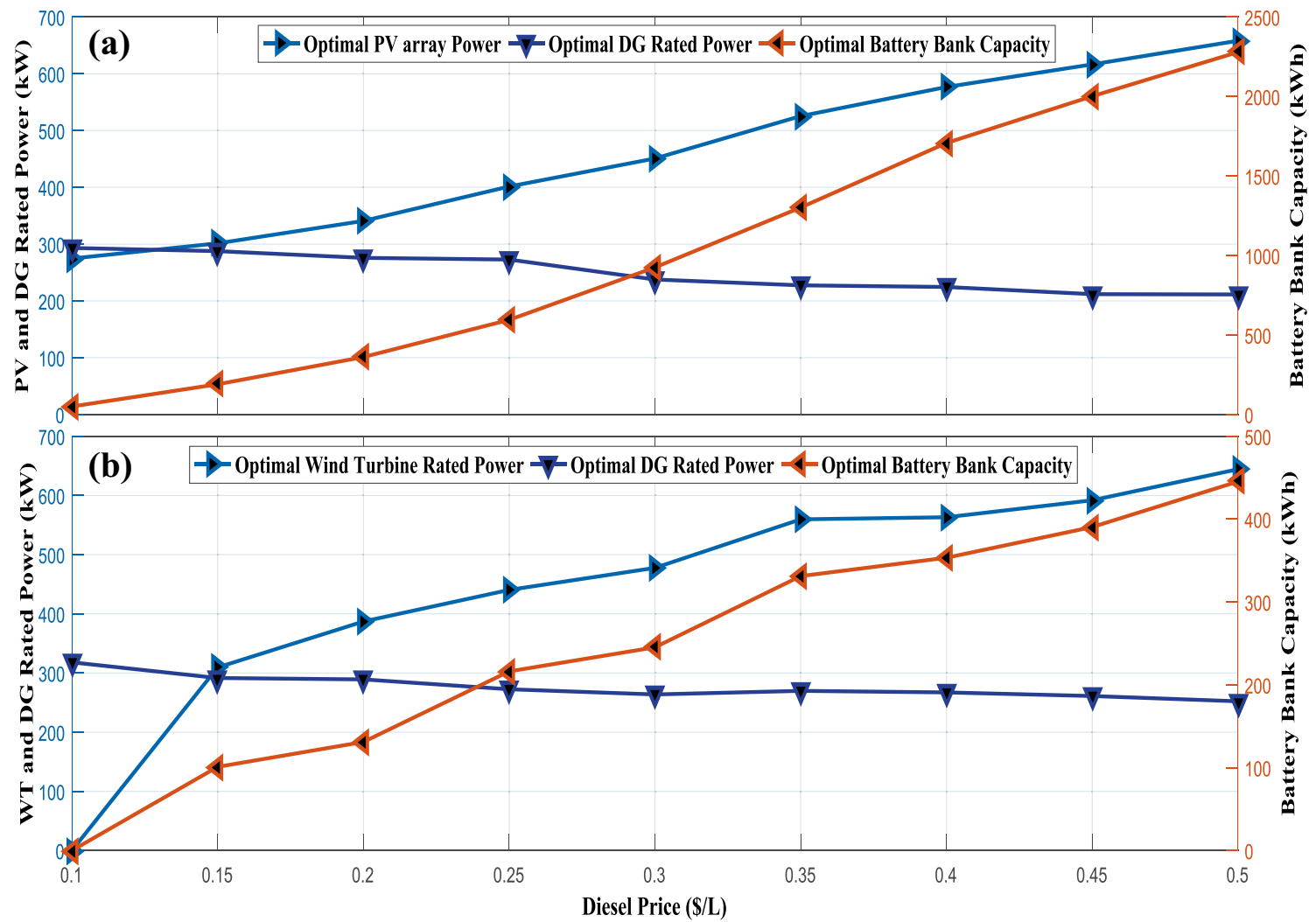

Fig. 9 Impact of diesel price on system component size for LPSP 0\% (a) PV/battery/diesel (b) wind/battery/diesel 


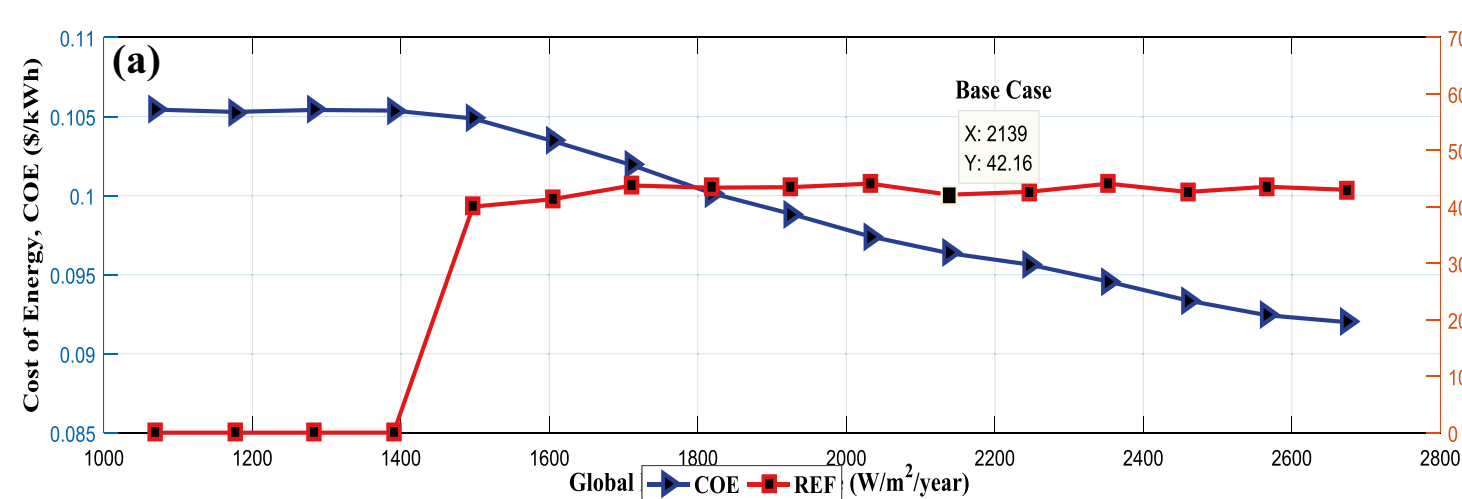

ר)

Fig. 10 Optimal HES for PV array cost of $1000 \$ / \mathrm{kW}$, wind turbine cost of 1300\$/kW and diesel price of 0.13\$/L (a) PV/battery/diesel (b) wind/battery/diesel
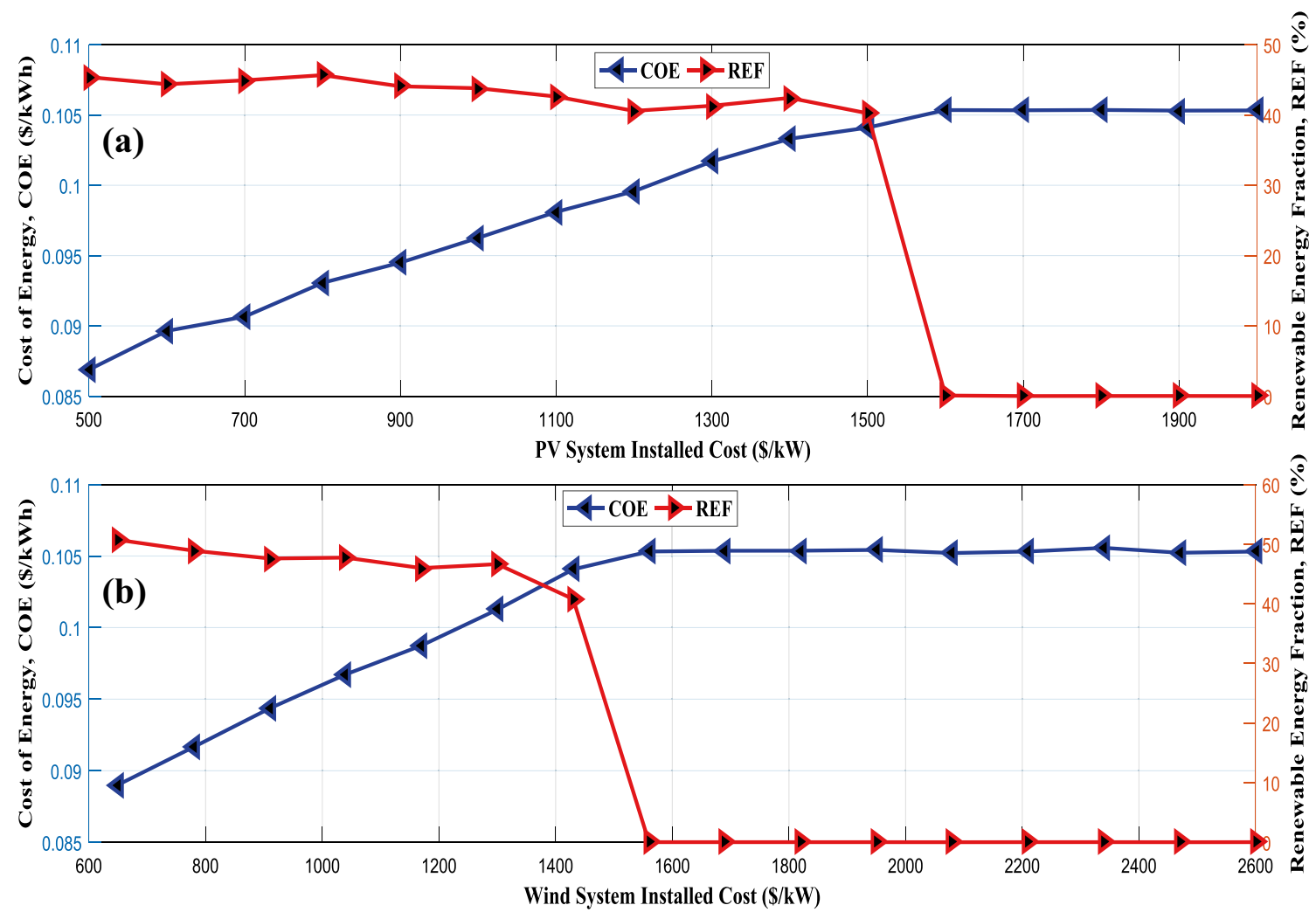

Fig. 11 Impact of system components cost on optimal system type for diesel price of $0.13 \$ / \mathrm{L}$ and LPSP of $0 \%$ 
and $650 \mathrm{~kW}$ with battery banks between 0 and $2200 \mathrm{kWh}$ is more cost-effective than the other systems. It can be also noticed that the storage requirements of PV/battery/ diesel system is much higher than that of wind/battery/diesel system due to the fact that proposed location has more fluctuating solar radiation as compared to wind speed, as shown in Fig. 9.

The effect of renewable resources variation on the optimal HES is presented in graphical form in Fig. 10. The most significant importance of this figure is that it can be used in the assortment of HES at other locations in Northern part of Saudi Arabia. The location covered by each HES is strongly dependent on the renewable resources variation and diesel price. It can be observed from Fig. 10 that the hybrid systems is the most economically choice even if the solar radiation decreases to half. Figure 10 also shows that irrespective of the wind speed, $\mathrm{PV} / \mathrm{battery} /$ diesel system is the optimal choice if the wind speed is less than about $6.75 \mathrm{~m} / \mathrm{s}$. At solar radiation and wind speed less than $1500 \mathrm{~W} / \mathrm{m}^{2}$, $5.6 \mathrm{~m} / \mathrm{s}$, respectively, diesel only system is cost effective.

The effects of PV and WT cost on the optimal HES are shown in Fig. 11. It can be observed that the PV/battery/ diesel system is the most viable choice when PV array cost is less than $1600 \$ / \mathrm{kW}$. It can further be observed from Fig. 11 that optimal renewable penetration ratio increases as the renewable cost decreases, for a given diesel price. Furthermore, for a given diesel price, the wind/battery/diesel system is the viable choice when WT cost is higher than $1600 \$ / \mathrm{kW}$.

\section{Conclusion}

In this study, the techno-economic prospective of transitioning the isolated area in Saudi Arabia is evaluated. The optimal sizing methodology of PV/battery/diesel, PV/Diesel and wind/battery/diesel hybrid energy conversion systems to supply the load demand of rural area has been proposed under different fuel cost scenarios. The optimization approach takes into account the effects of fuel cost on optimal renewable penetration ratio, component size and COE. The technical model is modeled based on LPSP and renewable penetration ratio whereas economic model is developed based on COE. Results first showed that, the PV systems are the most economical option to supply the load requirements. The elimination of fuel cost subsidies decreases the role of diesel generator in energy production by about $20-55 \%$. In detail, it was found that if Saudi Arabia eliminates the fuel cost subsidies, the COE of the DG only system increases by more than $41.3 \%$ as compared to the HES based on diesel prices of $0.5 \$ / L i t e r$. It found also that the storage system has a significant effect on the COE figures and the presence of batteries to the HES diminishes the diesel generator requirements and hence decreases the fuel consumption.
Open Access This article is licensed under a Creative Commons Attribution 4.0 International License, which permits use, sharing, adaptation, distribution and reproduction in any medium or format, as long as you give appropriate credit to the original author(s) and the source, provide a link to the Creative Commons licence, and indicate if changes were made. The images or other third party material in this article are included in the article's Creative Commons licence, unless indicated otherwise in a credit line to the material. If material is not included in the article's Creative Commons licence and your intended use is not permitted by statutory regulation or exceeds the permitted use, you will need to obtain permission directly from the copyright holder. To view a copy of this licence, visit http://creativecommons.org/licenses/by/4.0/.

\section{References}

1. Elhadidy, M.A., Shaahid, S.M.: Technical and economic assessment of grid-independent hybrid photovoltaic-diesel-battery power systems for commericial loads in desert environments. Renew. Sustain. Energy Rev. 11(8), 1794-1810 (2007)

2. Balachandra, P., Ravindranath, N.H., Deepak, P.K.: Grid-connected versus stand-alone energy systems for decentralized power a review of literature. Renew. Sustain. Energy Rev. 13, 2041-2050 (2009)

3. Lou, C., Li, Z., Lin, L., Zhou, H.Y.W.: Current status of research on optimum sizing of stand-alone hybrid solar-wind power generation systems. Appl. Energy 87, 380-389 (2010)

4. Lu, L., Zhou, W., Yang, H.X.: A novel optimization sizing model for hybrid solar-wind power generation system. Sol. Energy 81(1), 76-84 (2007)

5. Wang, C., Strunz, K., Aki, H., Ramakumar, R., Bing, J., Miao, Z., Salameh, Z., Nehrir, M.H.: A review of hybrid renewable/alternative energy systems for electric power generation: configurations, control and applications. IEEE Trans. Energy Convers. 2, 392-403 (2011)

6. Uzunoglu, M., Erdinc, O.: Optimum design of hybrid renewable energy systems: overview of different approaches. Renew. Sustain. Energy Rev. 16, 1412-1425 (2012)

7. Saberi, M., Alireza, S.M., Ardakani, F.J., Riahy, G.H.: Optimal sizing of hybrid PV and wind energy system with backup of redox flow battery to postpone grid expansion investments. J. Renew. Sustain. Energy 10, 1-19 (2018)

8. Lu, L., Zhou, W., Yang, H.X.: A novel optimization sizing model for hybrid solar-wind power generation system. Sol. Energy 81, 76-84 (2007)

9. Notton, G., Belhamel, M., Haddadi, M., Louche, A., Daif, S.: Design and techno-economical optimization for hybrid PV/wind system under various meteorological conditions. Appl. Energy 85, 968-987 (2008)

10. Belhamel, M., Ibtiouen, R., Kaabeche, A.: Sizing optimization of grid-independent hybrid photovoltaic/wind power. Sol. Energy 85, 2407-2420 (2011)

11. Ferrari, L., Bianchini, A., Galli, G., Ferrara, G., Carnevale, E.A.: Influence of actual component characteristics on the optimal energy mix of a photovoltaic-wind-diesel hybrid system for a remote off-grid application. J. Clean. Prod. 178, 206-2019 (2018)

12. Ismail, M.S., Moghavvemi, M., Mahlia, T.M.I.: Techno-economic analysis of an optimized photovoltaic and diesel generator hybrid power system for remote houses in a tropical climate. Energy Convers. Manag. 69, 163-173 (2013)

13. Al-Shamma'a, A.A., Addoweesh, K.E.: Techno-economic optimization of hybrid power system using genetic algorithm. Int. J. Energy Res. 38, 1142-1155 (2014) 
14. Saudi Electicity Annual report, "Annual repot," Saudi Electricity company (SEC), Riyadh, 2010,http://www.se.com.sa/SEC/Engli $\mathrm{sh} /$ Panel/Reports

15. Dubey, K., Howarth, N., Krarti, M.: Evaluating building energy efficiency investment options for Saudi Arabia. Riyadh, Kapsarc (2016)

16. National Renewable Energy Laboratory (NREL). Homer-Analysis of micro power system options. http://analysis.nrel.gov/homer/ default.asp

17. Pallabazzer, R.: Evaluation of wind generator potential. Sol. Energy 55, 49-59 (1995)

18. Johnson, G.L.: Wind energy systems. Prentice Hall, New Jersey (1985)

19. Ulhen, K., Skarstein, O.: Design considerations with respect to long-term diesel saving in wind/diesel plants. Wind Eng. 13, 72-87 (1989)

20. Nayar, C.V., Ashari, M.: An optimum dispatch strategy using set points for a photovoltaic (PV)-diesel-battery hybrid power system. Sol. Energy 66, 1-9 (1999)

21. Zhang, L., Barakat, G., Belfkira, R.: Optimal sizing study of hybrid wind/PV/diesel power generation unit. Sol. Energy 36, 100-110 (2011)
22. Kolokotsa, D., Potirakis, A., Kalaitzakis, K., Koutroulis, E.: A Methodology for optimal sizing of stand-alone photovoltaic/ wind-generator systems using genetic algorithms. Sol. Energy 80, 1072-1088 (2006)

23. Human, G., Schoor, G., Uren, K.R.: Power management and sizing optimisation of renewable energy hydrogen production systems. Sustain. Energy Technol. Assess. 31, 155-166 (2019)

24. Maria Isabel Blanco: The economics of wind energy. Renew. Sustain. Energy Rev. 13, 1372-1382 (2009)

25. Elshurafaa, A.M., Alsubaieb, A.M., Alabduljabbarb, A.A., AlHsaienc, S.A.: Solar PV on mosque rooftops: results from a pilot study in Saudi Arabia. J. Build. Eng. 25, 1-11 (2019)

Publisher's Note Springer Nature remains neutral with regard to jurisdictional claims in published maps and institutional affiliations. 